\title{
PERBEDAAN HASIL BELAJAR MATEMATIKA SISWA ANTARA MODEL PEMBELAJARAN KOOPERATIF TIPE NUMBERED \\ HEAD TOGETHER (NHT) DENGAN MAKE A MATCH \\ DI KELAS X SMA SWASTA ESA PRAKARSA SELESAI TAHUN AJARAN 2018/2019
}

\author{
Imelda Wardani Br. Rambe, Ika Sulistia \\ STKIP Budidaya Binjai \\ Email: imelda_wardani22@yahoo.com
}

\begin{abstract}
ABSTRAK
Penelitian ini bertujuan untuk mengetahui Perbedaan Hasil Belajar Matematika Siswa Antara Model Pembelajaran Kooperatif Numbered Head Together (NHT) Dengan Make A Match Di Kelas X SMA SWASTA ESA PRAKARSA SELESAI Tahun Ajaran 2018/2019. Jenis penelitian ini menggunakan jenis penelitian dengan metode eksperimen, sampel diambil secara acak (random sampling) dari 3 kelas diambil sebanyak 2 kelas, yaitu kelas X-1 sebagai kelas Eksperimen A dan kelas X-2 sebagai kelas Eksperimen B. Desain penelitian ini menggunakan $A$ Three Treatment Counter Balanced Design. Instrumen yang digunakan adalah instrumen tes hasil belajar matematika siswa berbentuk uraian. Uji prasyarat yang digunakan adalah uji Liliefors untuk menguji normalitas data, sedangkan Uji Fisher untuk menguji homogenitas data. Berdasarkan hasil uji normalitas diperoleh bahwa kedua populasi berdistribusi normal. Dan dari hasil uji homogenitas diperoleh bahwa kedua populasi homogen. Berdasarkan hasil analisis posstest matematika siswa antara kelas Eksperimen A dan kelas Eksperimen B yang lebih meningkatkan hasil belajar siswa adalah kelas Eksperimen A yang menggunakan model pembelajaran kooperatif tipe Numbered Head Together (NHT). Hal ini dapat disimpulkan bahwa $\mathrm{H}_{\mathrm{o}}$ ditolak dan $\mathrm{H}_{\mathrm{a}}$ diterima, sehingga dalam penelitian ini terdapat perbedaan hasil belajar siswa antara yang diberi pembelajaran Numbered Head Together (NHT) dengan pembelajaran Make A Match.

Kata Kunci : Hasil Belajar Matematika Siswa, Pembelajaran Numbered Head Together (NHT) dan Pembelajaran Make A Match
\end{abstract}

\section{PENDAHULUAN}

Matematika adalah mata pelajaran yang sangat mempengaruhi perkembangan ilmu pengetahuan dan teknologi yang semakin berkembang. Matematika tidak hanya mampu melatih kemampuan berhitung, tetapi juga mampu melatih cara berfikir kritis, menganalisis masalah, mengevaluasi hingga akhirnya mampu memecahkan suatu masalah.

Proses belajar mengajar juga memerlukan variasi guna meningkatkatkan mutu pendidikan. Variasi dalam proses belajar mengajar ditunjukkan oleh seorang 
guru dengan adanya perubahan dalam gaya mengajar, variasi media yang digunakan dan adanya perubahan dalam pola interaksi antara guruu dengan siswa, siswa dengan guru dan siswa dengan siswa. Adapun yang menjadi tujuan sekaligus tugas utama dari seorang guru tidak lain adalah mencerdaskan kehidupan bangsa. Artinya guru merupakan agen dalam pembelajaran.

Horward Kingsley dalam Abdurrahman (2018:202) membagi tiga macam hasil belajar yakni: (1) keterampilan dan kebiasaan; (2) pengetahuan dan pengertian; (3) sikap dan cita-cita. Masing-masing jenis hasil belajar dapat diisi dengan bahan yang telah ditetapkan dalam kurikulum". Hasil belajar merupakan hal yang sangat penting dalam pendidikan dan dapat dipandang sebagai salah satu ukuran keberhasilan siswa dalam pendidikan disekolah. Hasil belajar adalah penilaian pendidikan tentang kemajuan siswa dalam segala hal yang dipelajari di sekolah menyangkut pengetahuan, kecakapan atau keterampilan yang dinyatakan sesudah penilaian.

Rendahnya hasil belajar siswa dipengaruhi oleh dua faktor, yaitu faktor internal dan eksternal. Menurut Sumiati (2016: 25-26) "Faktor internal adalah faktor yang ada pada diri sendiri meliputi kemampuan dasar, baik kemampuan dasar umum (kecerdasan), maupun kemampuan dasar khusus (bakat), kesiapan untuk melakukan kegiatan dalam proses pembelajaran, minat untuk melakukan sesuatu kegiatan tertentu, pengalaman belajar yang telah dimiliki sebelumnya, dan kemampuan atau motivasi untuk belajar. Sedangkan faktor eksternal adalah faktor yang datang dari luar diri meliputi semua upaya yang dilakukan oleh guru, baik dalam memberikan rangsangan, bimbingan, pengarahan dan dorongan untuk terjadinya proses belajar".

Secara umum faktor yang paling berpengaruh terhadap rendahnya hasil belajar matematika siswa adalah kurang kreatifnya guru sebagai pendidik dalam melakukan kegiatan pembelajaran, seperti penggunaan model pembelajaran ataupun metode pembelajaran. Pernyataan ini sejalan dengan Trianto (2016: 5-6) menyatakan “ Di pihak lain secara empiris, berdasarkan hasil analisis penelitian terhadap rendahnya hasil belajar peserta didik yang disebabkan domainnya proses pembelajaran konvensional. Pada pembelajaran ini suasana kelas cenderung 
teacher - centered sehingga siswa menjadi pasif". Hal tersebut membuat siswa merasa bosan dan kurang menarik sehingga merasa malas untuk mengikuti pembelajaran. Proses pembelajaran juga dilakukan secara monoton, sehingga yang terjadi hanyalah penyampaian materi secara satu arah. Hal tersebut menjadikan suasana menjadi vakum (pasif) dan tidak adanya interaksi sesama siswa, bahkan siswa kepada guru.

Berdasarkan observasi yang dilakukan penulis pada guru matematika SMA Swasta Esa Prakarsa Selesai dapat diperoleh keterangan bahwa hasil belajar matematika siswa di kelas $\mathrm{X}$ masih sangat rendah. Hal ini dapat dilihat dari hasil ujian akhir semester lalu, seluruh hasil belajar siswa masih dibawah Kriteria Ketuntasan Maksimal (KKM) yaitu dibawah nilai 75. Dari 100 siswa nilai tertinggi yang diperoleh siswa dengan rentang skor 0-100 adalah 50 dan nilai terendah yang diperoleh siswa adalah 5. Dari data tersebut masih banyak siswa yang belum mencapai KKM. Untuk mengatasinya diperlukan alternatif penyelesaiannya dengan menggunakan model pembelajaran yang tepat. Penggunaan model pembelajaran yang tepat merupakan solusi yang sangat membantu dalam peningkatan hasil belajar siswa serta partisipasi siswa secara aktif dalam proses pembelajaran.

Matematika ilmu tentang logika yang mempelajari tentang bentuk, susunan, yang berperan penting dalam memajukan pola pikir manusia. Matematika juga merupakan salah satu peranaan penting dalam bidang pendidikan. Cornelius dalam Abdurrahman (2018:204) mengemukakan bahwa matematika perlu diajarkan kepada siswa karena: (1) sarana berfikir yang jelas dan logis; (2) sarana untuk memecahkan masalah dalam kehidupan sehari-hari; (3) sarana mengenal pola-pola hubungan masalah kehidupan sehari-hari; (4) sarana mengembangkan kreatifitas; dan (5) sarana untuk meningkatkan kesadaran terhadap perkembangan budaya.

Pembelajaran kooperatif adalah salah satu model pembelajaran yang memungkinkan siswa belajar dalam kelompok kecil atau tim untuk saling membantu, saling mendiskusikan dan berargumen dalam menyelesaikan atau mengerjakan tugas untuk mencapai tujuan bersama dalam pembelajaran. 
Dalam proses pembelajaran terdapat beberapa model pembelajaran kooperatif yang dapat digunakan salah satunya adalah model pembelajaran kooperatif tipe Numbered Head Together (NHT) dan Make A Match. Istarani (2015:12) mengatakan bahwa "Pembelajaran kooperatif tipe Numbered Heads Together (NHT) merupakan rangkaian penyampaian materi dengan menggunakan kelompok sebagai wadah dalam menyatukan persepsi/pikiran siswa terhadap pertanyaan yang dilontarkan atau diajukan oleh guru, yang kemudian akan dipertanggung jawabkan oleh siswa sesuai dengan nomor permintaan guru dari masing-masing kelompok. Dengan demikian, dalam kelompok siswa diberi nomor masing-masing sesuai dengan nomor urutannya”. Sedangkan model pembelajaran kooperatif tipe Make A Match adalah pembelajaran yang di kembangkan dengan menggunakan potongan-potongan kartu, dimana kartu-kartu yang digunakan berisi soal dan kartu jawaban yang di cocokkan sesusai jawaban kartu yang telah di tentukan. Shoimin (2013:108) mengatakan bahwa " Make A Match adalah jenis pembelajaran kooperatif yang siswa disuruh mencari pasangan kartu yang merupakan jawaban/soal sebelum batas waktunya, siswa yang dapat mencocokkan kartunya diberi poin.

Jadi, dapat disimpulkan bahwa model pembelajaran kooperatif tipe Numbered Head Together (NHT) memiliki tujuan untuk mendorong siswa berfikir dalam suatu tim dan berani tampil mandiri. Sedangkan model pembelajaran Make A Match memiliki tujuan siswa dapat mencari pasangan sambil belajar mengenai suatu konsep atau topik. Maka tujuan dari penelitian ini adalah untuk melihat Perbedaan Hasil Belajar Matematika Siswa Antara Model Pembelajaran Kooperatif Tipe Numbered Head Together (NHT) Dengan Make A Match Di Kelas X SMA Swasta Esa Prakarsa Selesai.

\section{METODE}

Penelitian ini dilaksanakan di SMA Swasta Esa Prakarsa Selesai, Kec. Selesai, Kab. Langkat. Waktu penelitian dimulai pada bulan Agustus 2018 tepatnya pada semester ganjil tahun ajaran 2018/2019. 
Populasi dalam penelitian ini adalah seluruh siswa kelas X SMA Swasta Esa Prakarsa Selesai Tahun Ajaran 2018/2019 yang terdiri dari 3 kelas dengan jumlah siswa 104 orang. Menurut Sugiono (2012:118) "Populasi adalah wilayah generalisasi yang terdiri atas: obyek/subyek yang mempunyai kualitas dan karakteristik tertentu yang ditetapkan oleh peneliti untuk dipelajari dan kemudian ditarik kesimpulannya". Adapun sampel yang digunakan dalam penelitian ini adalah 2 kelas yaitu kelas X-1 dan X-2 SMA Swasta Esa Prakarsa Selesai Tahun Ajaran 2018/2019, dimana kelas X-1 yang berjumlah 33 siswa sedangkan X-2 yang berjumlah 35 siswa.. Menurut Sugiono (2012:118) “ Sampel adalah bagian dari jumlah dan karakteristik yang dimilki oleh populasi tersebut".

Jenis penelitian ini adalah penelitian eksperimen. Penelitian ini melibatkan dua kelas yaitu kelas eksperimen A dan kelas eksperimen B, dimana kedua kelas ini di beri perlakuan yang berbeda. Pada kelas eksperimen A di beri perlakuan yaitu pengajaran dengan menggunakan pembelajaran kooperatif tipe Numbered Head Together (NHT) sedangkan di kelas B di beri perlakuan yaitu pengajaran dengan menggunakan pembelajaran kooperatif tipe Make A Match. Untuk mengetahui hasi belajar siswa yang diperoleh dari penerapan dua perlakuan tersebut, maka siswa diberikan tes sebanyak dua kali yaitu tes yang diberikan sebelum perlakuan $\left(\mathrm{T}_{1}\right)$ yang disebut pre-test. Selanjutnya pada kelompok eksperimen A diberikan perlakuan $\left(\mathrm{X}_{1}\right)$ dan pada kelompok eksperimen B diberi perlakuan $\left(\mathrm{X}_{2}\right)$. Sesudah selesai perlakuan kedua kelas diberi tes lagi $\left(\mathrm{T}_{2}\right)$ yang disebut post-test. Dan bentuk desain penelitian yang digunakan pada penelitian ini adalah A Three Treatment Counter balanced Design, dengan pola sebagai berikut:

Tabel. 1. Desain Penelitian

\begin{tabular}{|c|c|c|c|}
\hline Kelas & Pretest & Perlakuan & Postest \\
\hline Eks A & $\mathrm{T}_{1}$ & $\mathrm{X}_{1}$ & $\mathrm{~T}_{2}$ \\
\hline Eks B & $\mathrm{T}_{1}$ & $\mathrm{X}_{2}$ & $\mathrm{~T}_{2}$ \\
\hline
\end{tabular}

Keterangan:

$\mathrm{T}_{1}$ : Tes awal (Pre-test)

$\mathrm{T}_{2}$ : Tes akhir (Post-test)

$\mathrm{X}_{1}$ : Pembelajaran kooperatif tipe

NHT. 
$\mathrm{X}_{2}$ : Pembelajaran kooperatif tipe

Make A Match.

Instrumen penelitian dalam penelitian ini adalah tes hasil belajar siswa berupa pretest dan posttest. Tes yang digunakan dalam penelitian ini berupa tes tertulis berbentuk uraian. Peneliti menggunakan tes tertulis berbentuk uraian untuk menghindari sistem menebak. Tes ini digunakan untuk mengukur hasil belajar matematika siswa. Sebelum tes digunakan pada sampel, maka lebih dahulu tes tersebut diuji cobakan ke kelas lain untuk melihat validitas tes dan reliabilitas tes, tingkat kesukaran soal, dan daya beda soal. Untuk menguji hipotesis digunakan uji statistik t. Uji ini digunakan untuk menguji hipotesis apakah kebenarannya dapat diterima atau tidak. Dan syarat untuk menguji t adalah data harus normal dan homogen. Pengujian ada tidaknya perbedaan hasil belajar kelas eksperimen A dan kelas eksperimen B digunakan (uji t) dengan hipotesis :

Uji ini dilakukan untuk membuktikan hipotesis. Hipotesis nihil $\left(H_{0}\right)$ dan hipotesis alternatif $\left(H_{a}\right)$ yang diajukan dalam penelitian ini sebagai berikut :

$\mathrm{H}_{0}$ : "Tidak terdapat perbedaan hasil belajar matematika siswa antara model pembelajaran kooperatif tipe Numbered Head Together dengan pembelajaran Make A Match”.

$\mathrm{H}_{a}$ : "Terdapat perbedaan hasil belajar matematika siswa antara model pembelajaran kooperatif tipe Numbered HeadTogether dengan Make A Match”.

\section{HASIL DAN PEMBAHASAN}

Penelitian mengenai hasil belajar matematika siswa ini dilakukan di SMA Swasta Esa Prakarsa Selesai. Populasi dalam penelitian ini adalah siswa kelas X SMA Swasta Esa Prakarsa Selesai yang terdiri dari 3 kelas. Setelah menentukan populasi, langkah selanjutnya yaitu pemilihan sampel dengan menggunakan teknik Cluster Random Sampling. Dari proses sampling terhadap tiga kelas yang ada, diperoleh sampel yaitu kelas X-1 sebanyak 33 siswa sebagai kelas eksperimen A yang diajarkan dengan menggunakan pembelajaran Numbered Head Together dan kelas X-2 sebanyak 35 siswa sebagai kelas eksperimen B yang 
diajarkan dengan menggunakan pembelajaran Make A Match. Jenis penelitian dalam penelitian ini adalah eksperimen dan desai penelitiannya dengan menggunakan A Three Treatment Counter balanced Design. Tujuan utama diadakan penelitian ini adalah untuk mengetahui perbedaan hasil belajar matematika siswa yang menggunakan model pembelajaran kooperatif tipe Numbered Head Together dengan Make A Match di kelas X SMA Swasta Esa Prakarsa Selesai.

Dari hasil pemberian pretest dikelas eksperimen A dan kelas eksperimen $\mathrm{B}$, diperoleh nilai tertinggi untuk kelas eksperimen A adalah 50 dan nilai terendah adalah 10 serta jumlah nilai siswa adalah 825. Untuk kelas eksperimen B, diperoleh nilai tertinggi adalah 45 dan nilai terendah 5 serta jumlah nilai siswa adalah 790.

Berdasarkan data hasil penelitian pretest dan analisis data pada kedua kelas sampel penelitian berupa perhitungan untuk nilai rata-rata, standr deviasi dan varians. Secara ringkas diperlihatkan pada tabel berikut:

Tabel. 2. Analisis Data Pretest Kelas Eksperimen A dan Kelas Eksperimen B

\begin{tabular}{|c|l|c|c|}
\hline \multirow{2}{*}{ No } & \multirow{2}{*}{ Statistik } & \multicolumn{2}{|c|}{ Kelas } \\
\cline { 3 - 4 } & & Eks A & Eks B \\
\hline 1 & Rata-Rata & 24,67 & 22,80 \\
\hline 2 & Standar Deviasi & 103,10 & 140,58 \\
\hline 3 & Varians & 10,15 & 11,86 \\
\hline
\end{tabular}

Setelah diketahui kemampuan awal kedua kelas tersebut, maka dilakukan pembelajaran dengan dua model pembelajaran yang berbeda di kelas eksperimen A maupun kelas eksperimen B.Kelas eksperimen A diterapkan pembelajaran dengan model pembelajaran kooperatif tipe Numbered Head Together, sedangkan kelas eksperimen B diterapkan pembelajaran dengan model pembelajaran tipe Make A Match. Pada akhir pertemuan, siswa diberikan posttest. Tujuan diberikannya posttest adalah untuk mengetahui hasil belajar siswa setelah dilakukan pembelajaran dengan model pembelajaran kooperatif tipe Numbered Head Together dengan Make A Match .Dari data posttest, diperoleh nilai tertinggi untuk kelas eksperimen A adalah 85 dan nilai terendah adalah 45 serta jumlah 
nilai siswa adalah 2250. Untuk kelas eksperimen B, diperoleh nilai tertinggi adalah 75 dan nilai terendah 15 serta jumlah nilai siswa adalah 1630 .

Berdasarkan data hasil penelitian posttest pada kedua kelas sampel penelitian dan dilakukan analisis data berupa perhitungan untuk nilai rata-rata, standart deviasi dan varians. Secara ringkas diperlihatkan pada tabel berikut:

Tabel. 3. Analisis Data Posttest kelas Eksperimen A dan Kelas Eksperimen B

\begin{tabular}{|c|l|c|c|}
\hline \multirow{2}{*}{ No } & \multirow{2}{*}{ Statistik } & \multicolumn{2}{|c|}{ Kelas } \\
\cline { 3 - 4 } & & Eks A & Eks B \\
\hline 1 & Rata-Rata & 68,03 & 44,99 \\
\hline 2 & Standar Deviasi & 95,11 & 306,39 \\
\hline 3 & Varians & 9,75 & 17,50 \\
\hline
\end{tabular}

Dari data hasil belajar siswa berdasarkan nilai postest pada kelas ekperimen $\mathrm{A}$ dan kelas eksperimen $\mathrm{B}$ diperoleh perbedaan rata-rata hasil belajar siswa kelas eksperimen A sebesar 68,03 dan kelas eksperimen B sebesar 44,99. Sedangkan berdasarkan nilai pretest siswa, rata-rata hasil belajar siswa kelas eksperimen A sebesar 24,67 dan pada kelas eksperimen B sebesar 22,80. Dari data tersebut dapat diketahui bahwa rata-rata pretest siswa sebelum dilakukan pembelajaran relatif sama. Namun setelah diberikan model pembelajaran yang berbeda, diperoleh nilai rata-rata hasil belajar matematika siswa berbeda yakni pada kelas eksperimen a lebih tinggi dibandingkan dengan kelas eksperimen B.

Sebelum dilakukan uji hipotesis terlebih dahulu dilakukan uji prasyarat data yaitu uji normalitas untuk mengetahui apakah data yang diperoleh berdistribusi normal atau tidak.Pengujian normalitas data dilakukan dengan uji Lilliefors dengan ketentuan jika $\mathrm{L}_{0}<\mathrm{L}_{\text {tabel }}$ maka disimpulkan bahwa sebaran data berdistribusi normal dan demikian sebaliknya.Hasil perhitungan normalitas data secara ringkas dirangkum pada Tabel 4.

Tabel. 4. Ringkasan Hasil Uji Normalitas Data

\begin{tabular}{|l|c|c|c|c|}
\hline \multirow{2}{*}{ Kelas } & \multicolumn{2}{|c|}{$\boldsymbol{L}_{\text {hitung }}$} & \multirow{2}{*}{$\boldsymbol{L}_{\text {tabel }}$} & \multirow{2}{*}{ kriteria } \\
\cline { 2 - 3 } & pretest & postest & & \\
\hline Eks A & 0,1318 & 0,1480 & 0,1542 & Normal \\
\hline Eks B & 0,1454 & 0,0908 & 0,1542 & Normal \\
\hline
\end{tabular}


Berdasarkan kriteria pengujian yaitu menerima sampel yang berasal dari populasi yang berdistribusi normal jika $\mathrm{L}_{\text {hitung }}<\mathrm{L}_{\text {tabel }}$ pada $\alpha=0,05$ dan menolak kriteria pengujian jika $\mathrm{L}_{\text {hitung }}>\mathrm{L}_{\text {tabel }}$. Dari data di atas dapat dilihat bahwa $\mathrm{L}_{\text {hitung }}<$ $\mathrm{L}_{\text {tabel, }}$ hal ini berarti menerima kriteria pengujian bahwa sampel berasal dari populasi yang berdistribusi normal.

Untuk menguji apakah data homogen atau tidak, maka digunakan uji kesamaan dua varians dari masing-masing data pretest. Untuk menguji homogenitas dari data yang diperoleh selama penelitian, digunakan uji statistik-F. Untuk kriteria pengujian data kedua sampel adalah homogen jika $F_{\text {hitung }}<F_{\text {tabel }}$ pada taraf nyata $\alpha=0,05$. Hasil perhitungan homogenitas data secara ringkas dirangkum pada Tabel 5.

Tabel. 5. Ringkasan Hasil Uji Homogenitas

\begin{tabular}{|c|c|c|c|l|l|}
\hline \multirow{2}{*}{ Data } & \multicolumn{2}{|c|}{ Varians } & \multirow{2}{*}{ F $_{\text {hit }}$} & \multirow{2}{*}{ F $_{\text {tab }}$} & \multirow{2}{*}{ Kriteria } \\
\cline { 2 - 5 } & $\mathrm{A}$ & $\mathrm{B}$ & 0,733 & 1,783 & Homogen \\
\hline Pretes & 103,10 & 140,58 & 0,733 & Homogen \\
\hline Postes & 95,11 & 306,39 & 0,310 & 1,783 & Homoge \\
\hline
\end{tabular}

Dari tabel 5 di atas terlihat bahwa Fhitung< Ftabel baik data pretes maupun postes. Oleh karena itu, berdasarkan kriteria pengujian jika $F_{\text {hitung }}<F_{\text {tabel }}$, maka sampel memiliki varians yang sama atau homogen.

Berdasarkan pengujian normalitas dan homogenitas dari kelas eksperimen A dan kelas eksperimen B menunjukkan bahwa persyaratan analisis dalam penelitian ini berdistribusi normal dan bervariansi populasi homogen. Hal ini menunjukkan bahwa persyaratan analisis dalam penelitian ini terpenuhi, sehingga dapat dilanjutkan pada pengujian lebih lanjut yaitu pengujian hipotesis dengan uji statistik t. Hal ini menunjukkan bahwa hasil perhitungan hipotesis pretest dengan menggunakan uji-t diperoleh hasil rata-rata kelas Eksperimen A 68,03 dan kelas Eksperimen B 44,99 sehingga didapat $t_{\text {hitung }}=7,628$ dan $t_{\text {tabel }}=1,996$. Dengan demikian terlihat bahwa $t_{\text {hitung }}<t_{\text {tabel }}$ ini berarti $\mathrm{H}_{\mathrm{a}}$ diterima dan $\mathrm{H}_{0}$ ditolak, sehingga dapat disimpulkan bahwa terdapat perbedaan posttest pada hasil belajar matematika siswa antara kelas Eksperimen A yang menggunakan model pembelajaran Numbered Head Together (NHT) dengan kelas Eksperimen B yang 
menggunkan pembelajaran Make A Match. Secara ringkas hasil perhitungan uji hipotesis pada Tabel 6.

Tabel. 6. Ringkasan Hasil Uji Hipotesis

\begin{tabular}{|c|c|c|c|}
\hline $\begin{array}{c}\text { Data } \\
\text { Postes }\end{array}$ & $\begin{array}{c}\text { Nilai } \\
\text { rata-rata }\end{array}$ & $\mathbf{t}_{\text {hit }}$ & $\mathbf{t}_{\text {tabel }}$ \\
\hline Eks A & 24,67 & 0,926 & 1,996 \\
\hline Eks B & 22,80 & & \\
\hline
\end{tabular}

\section{SIMPULAN}

Berdasarkan analisis data dan pembahasan diperoleh $t_{\text {hitung }}=7,628$ dan $t_{\text {tabel }}=1,996$ sehingga $t_{\text {hitung }}>t_{\text {tabel }}$ maka $H_{o}$ ditolak dan $H_{a}$ diterima. Pada analisis posttest kelas Eksperimen A memperoleh nilai rata-rata 68,03 dengan simpangan baku 9,75 dan standar deviasi 95,11. Dan kelas Eksperimen B memperoleh nilai rata-rata 44,99 dengan simpangan baku 17,50 dan standar deviasi 306,39. Sehingga dapat disimpulkan bahwa adanya perbedaan hasil belajar matematika siswa antara model pembelajaran kooperatif tipe Numbered Head Together (NHT) dengan Make A Match di kelas X SMA Swasta Esa Prakarsa Selesai tahun ajaran 2018/2019.

\section{REFERENSI}

Abdurrahman, M. (2018). Anak Berkesulitan Belajar: Teori, Diagnosis,dan Remediasinya. Jakarta: Rineka Cipta.

Lailin Nurul Hidayati. Perbedaan Hasil Belajar Siswa yang Diajarkan dengan Model Pembelajaran Kooperatif Tipe NHT dan Tipe Make A Match pada Siswa Kelas VIII di MTs Negeri Tunggangri Tahun Ajaran 2015/2016

Sukmadinata, Nana Syaodih. (2012). Metode Penelitian Pendidikan. Bandung: Remaja Rosdakarya.

Shoimin, Aris. (2014). 68 Model Pembelajaran Inovatif dalam Kurikulum 2013. Yogyakarta: Ar-Ruzz Media.

Sugiono. (2012). Metode Penelitian Pendidikan (Pendekatan Kuantitatif, Kualitatif, dan $R \& D$, Bandung: ALFABETA.

Sumiati, Asra. (2016). Metode Pembelajaran, Bandung: CV Wacana Prima. 
Trianto. (2016). Mendesain Model Pembelajaran Inovatif-Progresif : Konsep,

Landasan , dan Implementasinya pada Kurikulum Tingkat Satuan Pendidikan (KTSP). Jakarta: Kencana. 